\author{
Bartłomiej H. Toszek \\ University of Szczecin (Poland) \\ Institute of Political and Security Sciences \\ e-mail: clermont@wp.pl \\ ORCID: https://orcid.org/0000-0003-2989-7168
}

\title{
The Battle of Brexit. Analysis of the 2019 United Kingdom General Election Results
}

\begin{abstract}
The article presents the main parties (i.e. the Conservative Party, Labor Party, Liberal Democrats and Scottish National Party) results of the 2019 UK general election as well as an analysis of the most important issues (i.e. correct identification of voters' expectations, simplicity and clarity of the messages, leaders' personalities) which determined each party success or loss. The author proves that since Brexit was the primary focus of voters, the level of support for particular parties remained dependent on the solutions presented in this issue. This basis explains why the Conservatives in the whole UK and the SNP in Scotland won (and the Labor Party and the Liberal Democrats lost) the battle of Brexit.
\end{abstract}

Keywords: Brexit, the United Kingdom, the European Union, the 2019 United Kingdom general election, Scotland

The 2019 United Kingdom general election was held for no reason but to break the prolonged parliamentary deadlock over conditions of Britain's withdrawal from the European Union (which caused the lack of the UK Government's ability to conducting effective negotiations with the EU authorities). In this context, the choice between main parties on the national level (i.e. the Conservatives, Labor, and Liberal Democrats) was tantamount to decide about further British relations with the EU.Additionally, in Scotland, the number of votes received by each of these parties and the Scottish National Party very clearly demonstrated what decision the Scots could make (in the referendum demanded by the SNP) on disconnecting their country from the United Kingdom in case of Brexit. Therefore, the importance of the election results should be considered in light of its impact on shaping Britain's future position towards Europe and the present (i.e. unitary) formula or even cohesion of the UK maintenance.

This article presents all (i.e. four) the main British parties (indicated above) the 2019 general election results and analyzed the most important formal (i.e. personalities of leaders 
and ways of running election campaign) and substantive (specified in election manifestos) factors determining each party success or failure. An author proves that proposed by the Conservatives, Labor, Liberal Democrats and Scottish Nationalists solutions for the UK withdrawal from the EU (and the future of Scotland inside or outside the UK) were crucial for the level of electorate support obtained. On this assumption predictions regarding the development of the Brexit (and Scotland's position) case are based. To achieve the pursued aim an author uses the comparative method (to compare analyzed parties' proposals on Brexit, public perception of their leaders and relevant aspects of their campaigns), microsystem analysis and decisive method (to clarify voters decisions in the identification with a particular value system context, i.e. their greater or lesser acceptance of analyzed parties' visions of the UK's relations with the EU).

\section{The Social Position and Political Views Stability of Voters}

In the 2019 general election took part $67,3 \%$ (i.e. 31.829.630) of the total number of 47.587.254 registered voters (1,5\% less than in the 2017 general election). As much as $43,6 \%$ (i.e. 13.966.451) of them voted for the Conservative Party, 32,2\% (i.e. 10.295.912) for the Labor Party, 11,5\% (i.e. 3.696.419) for the Liberal Democrats and 3,9\% (i.e. 1.242.380) for the SNP (which fields candidates only in Scottish constituencies). Such distribution of votes enabled these parties to take 365 (i.e. 56,2\%), 203 (i.e. 31,1\%), 11 (i.e. 1,7\%) and 48 (i.e. 7,4\%) parliamentary seats respectively. The other 23 of 650 seats were taken by regional parties of Northern Ireland (i.e. the Democratic Unionist Party, Sinn Fein, the Social Democratic and Labor Party and the Alliance Party) and Wales (Plaid Cymru) as well as the Green (Uberoi et al., 2020, p. 6). The opinion poll (on the group of 40.000 British adults) conducted after the election showed that the Conservatives had the biggest support in all social classes (from the non-working class to the upper-middle class) and groups defined based on income (from earning less than $£ 20.000$ to greater than $£ 70.000$ per year). However, the main part of their electorate was a group of both males and females, over 50 years old, with medium or lower education. By contrast, the Labor was the most popular in a group of young people (under the age of 30 years), especially women, studying or having completed tertiary (or equivalent) education levels. The Liberal Democrats received support mainly from middleaged people (between 30 and 60 years), highly educated and well-off, of the upper-middle class. The specificity of the SNP as the regional party (openly declaring its disinterest in all questions but connecting with Scotland) resulted in equal support in all groups defined based on social class, educational level and household earnings; some minor differences were visible only between people under the age of 50 years and elders of whom the first were more enthusiastic supporters of the Scottish Nationalists than the latter (Uberoi et al., 2020, pp. 53-56). This information's importance appears not fully until in relation to the data on the 2016 United Kingdom European Union membership referendum voters' preferences by age, social class, education, and household income status. As demonstrated 
in the opinion poll (on the group of 5.455 British adults) conducted after the referendum, the supporters of Brexit were mainly the people over 50 years old, of three lowest social classes (i.e. non-working, working and skilled working), below higher level of education and the household income less than $£ 39$.999. Most of them voted for the United Kingdom Independence Party, Conservative Party or did not vote in the 2015 UK general election (Uberoi, 2016, pp. 20-22). The same observations were made by the University of Warwick researchers who "shows that somewhat contrary to the popular wisdom, exposure to EU immigration and trade policy did not play a significant role in predicting a vote in favor of leaving the EU. On the other hand, education profiles, dependence on manufacturing employment, low income, and high unemployment appear to be correlated with support for Brexit" (Becker, Fetzer, Novy, 2017, p. 646).

To understand the reasons for the main nationwide parties' success or failure it is worth analyzing the British electorate's preferences between the 2017 and 2019 general elections. The opinion poll (on the group of 28.704 British adults voting in both elections) revealed

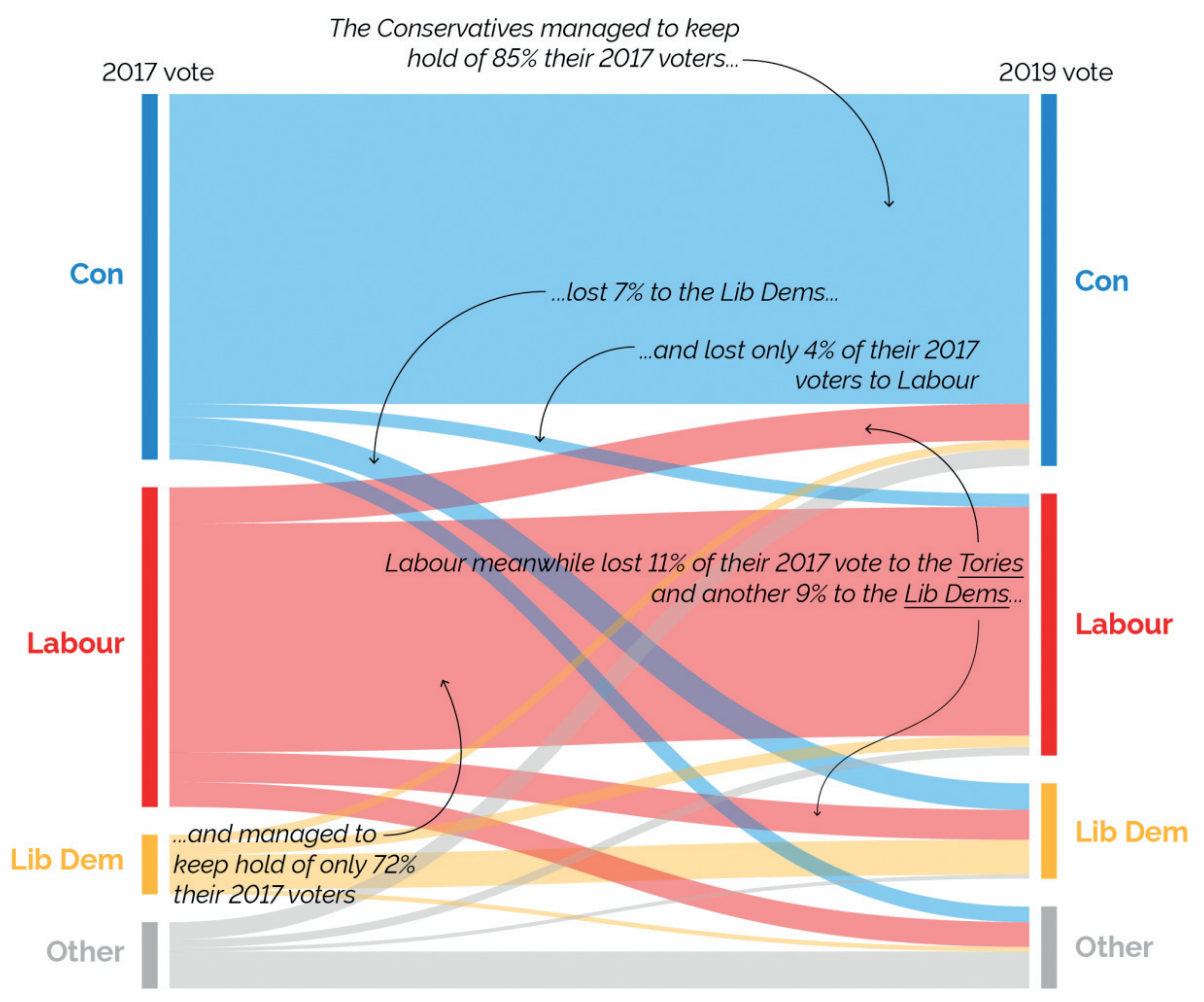

Figure 1. How 2017 voters voted at the 2019 UK general election Source: YouGov, 2019a. 
that $11 \%$ of people voting for the Conservatives in 2017 decided to transfer their support to the Liberal Democrats (7\%) or the Labor (4\%) two years later. Meanwhile the Conservative Party held $85 \%$ of its electorate and obtained $14 \%$ voters of the Liberal Democrats, $11 \%$ of the Labor Party and 67\% (sic!) of the UKIP. Almost $3 / 4$ of the Labor 2017 electorate voted for them in 2019 as well as many of the Green (34\%) and the Liberal Democrats (20\%) former supporters. The latter one suffered the biggest losses by keeping only $59 \%$ of former voters while the rest moved their support to the Greens (15\%), Labor (9\%), Conservatives (7\%), UKIP (3\%) and smaller parties (ca. 18\%). In this respect the SNP was in the best position of all regional (i.e. countrywide) parties because the vast majority (i.e. $87 \%$ ) of its voters did not change their political preferences (YouGov, 2019a).

\section{The Main Determinants of Voting Preferences}

The factor having the greatest impact on the distribution of votes between parties was undoubtedly the correct identification of the electorate's needs and expectations. Based on determinations made for $\mathrm{BBC}$ just before the 2019 general election, it was possible to conclude that while only ca. $25 \%$ of the British were interested in solutions to the crime, economy and immigration issues (in comparison with the 2015 general election when two latter issues had bigger interest of around $15 \%$ voters), and $35-40 \%$ to the National Health Service functioning (which was similar to the indications recorded four years earlier but much lower than ca. 65\% during the 2017 general election), for ca. $70 \%$ of them the most important issue was Brexit.

A similar conclusion was reached on results of the opinion poll (on the group of 1.606 British adults) which proved that "five weeks until (2019) December's election, Brexit remains

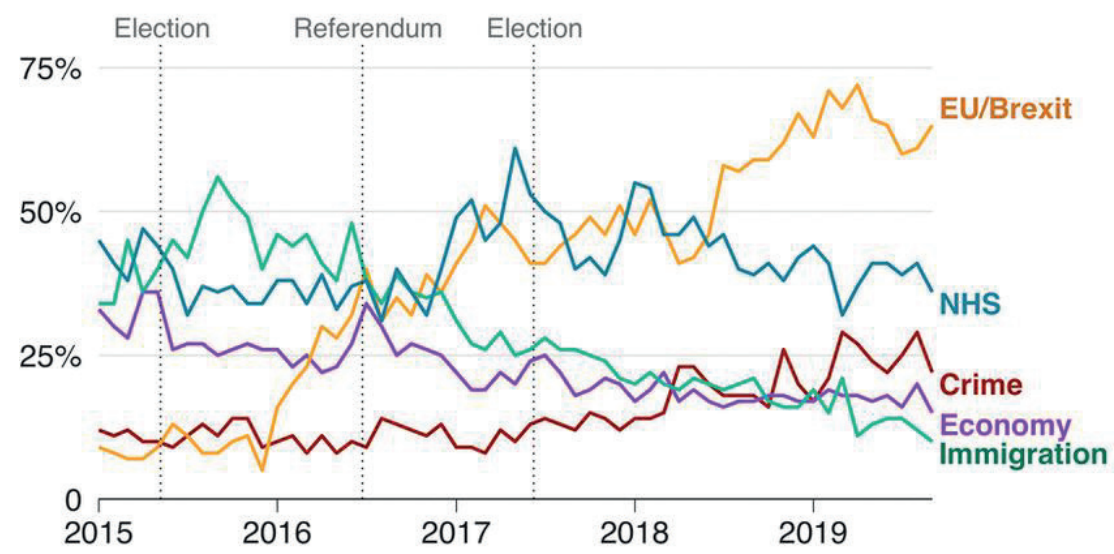

Figure 2. What did people feel were the most important issues facing Britain? Source: BBC News 2019a. 
the top issue for the British public. Some $68 \%$ of Britons rank it within their top three. (...) Healthcare currently sits in the second place behind Brexit, with $40 \%$ of the public placing it in their top three. (...) However, there have been some notable shifts. In 2017, 34\% of the British public considered the economy one of the three most important issues facing the country. Now, the economy places just outside the top three, falling 9 percentage points to $25 \%$. The issue of crime has jumped to become Brits' third most important issue. Indeed, there has been a dramatic increase in the significance of crime to the public. In early May 2017, just 11\% considered it one of the most important issues facing Britain. Now over one in four Brits (28\%) believe it is one of the most pressing issues facing the country today" (YouGov, 2019b).

\section{Why Did the Conservatives Win?}

During the 2019 general election campaign the Conservatives were strongly focused on some carefully targeted issues. They promised extra funding for the NHS (with 6.000 more doctors, 50.000 more nurses and 50 million more general practices surgery appointments a year); "20.000 more police and tougher sentencing for criminals; an Australian-style pointsbased system to control immigration; millions more invested every week in science, schools, apprenticeships and infrastructure while controlling debt; reaching Net-Zero by 2050 with investment in clean energy solutions and green infrastructure to reduce carbon emissions and pollution" (The Conservative and Unionist Party 2019: 1) as well as not to raise the income tax, VAT or National Insurance rates. However, their priority was obviously to "get Brexit done" in the short term (i.e. by the end of January 2020 with not extending the implementation period beyond December 2020) without further negotiations or referendums. As highlighted in the Conservatives' manifesto: "our deal is the only one on the table. It is signed, sealed and ready. It puts the whole country on a path to a new free trade agreement with the EU. It will be a new relationship based on free trade and friendly cooperation, not on the EU's treaties or EU law. There will be no political alignment with the EU. We will keep the EU out of the single market, out of any form of a customs union, and end the European Court of Justice's role. This future relationship will be one that allows us to: take back control of our laws; take back control back on our money; control our own trade policy; introduce an Australian-style (...) immigration system; rise standards in areas like workers' rights, animal welfare, agriculture and environment; ensure we are in full control of our fishing waters" (The Conservative and Unionist Party, p. 5). These arguments were repeated over and over again in any speech (reported in the media) of the Prime Minister and appeared "to have resonated with a public weary of the lack of resolution over the UK leaving the EU" (Mason, 2019, p. 4). Such tactics allowed in one go to eliminate the threat of the right-wing populists' (i.e. the UKIP and Brexit Party) obtaining votes of ("hard") Brexit supporters and to avoid the trap of the 2017 UK general election when the Conservatives (under Theresa May leadership) find themselves caught up in the futile dispute on a lot of economic and 
social issues (instead of the main one, i.e. Brexit). Not the least important was the personality of the Prime Minister. He was described as "politically nimble" (Channel4, 2012) or even "populist" (The New York Times, 2016) (because of regular changes of his political opinions), known for his awkwardness (sexist, homophobic and racist) opinions, clumsy behaviors (and therefore called "gaffe-prone") as well as for "semi-shambolic look" (Edwards, Isaby, 2008, p. 74) (by characteristic hairstyling), Boris Johnson appeared to be a much better political leader than his rivals (especially Jeremy Corbyn). Furthermore, in comparison to the other politicians (not only from the opposition parties but including even the leading figures of the Conservative Party) who often changed their minds on Brexit, the rigorous consistency in aiming at the UK withdrawal from the EU against all odds contributed to creating a positive image of B. Johnson as "the tough guy among softies". In conclusion, the Conservatives conducted their campaign with clearly, simply and briefly formulated postulates (especially on Brexit issue) and distinct (although controversial) leader who gave them a better start position than the Labor or Liberal Democrats.

\section{Reasons for the Labor Party's Failure}

In contrast to the Conservatives' manifesto the Labor's one was far more detailed. “There was an incredible amount on offer in (...) manifesto It's Time for Real Change. From free care for the elderly, free university tuition fees, reducing the voting age to 16 and payouts for WASPI (i.e. voluntary UK-based organization Women Against State Pension Inequality) women, the party attempted to speak to every sector of society. Some candidates reported that they had so much to rattle through on the doorstep that when policy ideas dropped halfway through the campaign - such as slashed rail fares - they shied away from discussing them so as not to overload people with commitments. A Labor source said: 'It wasn't the people didn't like the policies, people thought there was too many of them. The free broadband was really unpopular. We hadn't spent two years making the case for it and we just dumped it on them (...) so people thought: this is a weird luxury, why on earth are we being offered this?' Jon Lansman, leader of the (Jeremy) Corbyn campaign group (...) said: 'The manifesto was too detailed and too long. It was programme for 10 years, not for government” (Proctor, 2019, p. 5). In addition to the main manifesto the Labor published even more precise manifestos for particular social groups (i.e. "The Future is Ours: Youth Manifesto"' “A Charter for the Arts”, "Workers' Rights Manifesto", "Breaking Down Barriers: Labor's manifesto for disabled people"), each of nine English regions (i.e. the East of England, East Midlands, London, North East, North West, South East, South West, West Midlands, Yorkshire and the Humber) beside of conventionally standalone manifestos for Scotland and Wales, and related to some special issues (i.e."Labor Party Race \& Faith Manifesto," “Labor's Plan for Housing”, “A Plan for Nature: Our Manifesto for the Environment"). The overcomplicated character of the main manifesto in terms of the arrangement of content and the substance of proposed solutions was perfectly reflected the UK withdrawal from the EU issue. It was only placed after "A Green Industrial Revolution" 
and "Rebuilding Our Public Services" chapters which related to issues of minor relevance for the public. In their "final say on Brexit" the Labor promised a new deal with the EU including "a permanent and comprehensive UK-wide customs union, which is vital to protect our manufacturing industry and allows the UK to benefit from joint UK-EU trade deals, and is backed by businesses and trade unions; close alignment with the Single Market - ensuring we have a strong future economic relationship with the EU that can support UK businesses; dynamic alignment on worker's rights, consumer rights and environmental protections so that UK standards keep pace across Europe as a minimum, allowing the UK to lead the way, not fall behind; continued participation in EU agencies and funding programmes (...); clear commitments on future security arrangements, including access to the European Arrest Warrant and shared databases, making people safer at home and abroad. Labor will secure a revised Withdrawal Agreement that provides legal protection for citizens' rights, meet our international obligations (...) and ensures an appropriate transition period to allow businesses and citizens to adapt to any new arrangements. (...) Once we have secured this new deal we will put it to a legally binding referendum alongside the option of remaining in the EU" (The Labor Party, 2019, p. 90). There was thus a significant disparity between the real desire to maintain the UK membership in the $\mathrm{EU}$ (despite of the 2016 referendum result) and the unwilling consent to realize "soft Brexit" based on rather close relations with the EU (but keeping the UK beyond the essential forms of the EU members' unification) which caused the voters' confusion about the Labor's intentions on Brexit issue. Moreover, "the Labor leadership (...) blamed Brexit for overshadowing their radical domestic agenda, but others within the shadow cabinet believe their own approach to the EU was extremely unclear. The party's chair, Ian Lavery (...) told the BBC: 'what we are seeing in the Labor heartlands is the people very aggrieved at the fact the party basically has taken a stance on Brexit the way they have'. He said ignoring the wishes of 17,4 million voters was 'not a good recipe.' (...) Caroline Flint, who lost her seat in Don Valley, said the party had not taken the right approach considering the number of leave-voting seats it represented in the country" (Proctor, 2019, p. 5).

As the Labor's manifesto was too detailed as their pre-election activity was too expansive. The campaigns run with equal intensity both in major cities and small towns. "Rallies were held in (...) Birmingham and Bristol but also marginals such as Telford and Middlesbrough South and East Cleveland. Some activists complained that (...) (the party) focused its efforts only on ultra-marginal seats and those that had candidate aligned to its politics. This may have left some seats at risk with majorities of between 3.000 and 5.000, because the group did not always have a strong on-the-ground presence" (Proctor, 2019, p. 5). Quite unnecessary and as seemed to be motivated solely by exaggerated ambitions were serious endeavors to won in Uxbridge and South Ruislip as well as Chingford and Woodford Green where the Conservatives nominated their most popular leading politicians, i.e. B. Johnson and Iain Duncan Smith ${ }^{1}$. The Labors addressed their promises to a class-differentiated electorate

1 Sir George Iain Duncan Smith (b. 1954) is the Conservative Party politician. He was the Member 
which made them unable to pay due attention to many issues of particular importance for their traditional working-class base. This could not remain without consequence. The support of old coal, steel and manufacturing districts voters (the so-called "red wall") weakened which caused "seats such as Bolsover, Rother Valley, Blyth Valley, Darlington and Redcar turning Tory indicated a severing of Labor allegiances that in some cases span back 100 years" (Proctor, 2019, p. 5). However, this situation should not be surprising since even the Labor Party leader (i.e. Jeremy Corbyn), as a middle-class north Londoner, was unable to build close relationships with working-class voters in his own constituency. As a matter of fact, J. Corbyn caused the main image problem for the Labor. He was well known because of openly manifested sympathies for the British Section of the Fourth International (i.e. International Marxist Group) and Trotskyist entryist group designed to infiltrate the Labor (i.e. Militant) in the 1970s. Moreover, "Jeremy Corbyn personally led or took part in at least 72 separate events or actions with Sinn Fein and pro-republican groups during the years of the IRA'a armed struggle" (The Times, 2017). Because of a stern criticism of Israeli policy to Palestinians for decades (especially for supporting terrorists responsible for the 1994 bombing of the Israeli Embassy in London), J. Corbyn was repeatedly accused of antisemitism. Likewise, uncompromising was his approach to the UK withdrawal from the EU issue which made him unpopular among almost all "Brexiteers" (including those in the Labor Party). As a result, the opinion poll (on the group of 1.006 British adults) conducted three months before the 2019 general election showed J. Corbyn had "the lowest net satisfaction ratings of any opposition leader since the survey began in 1977" (Ipsos MORI, 2019a). Over three-quarters of Britons were dissatisfied with how he was doing his job as the leader of the opposition. The poll also revealed that J. Corbyn's leadership was positively evaluated only by $51 \%$ of the Labor Party supporters while the negative opinion expressed $41 \%$ of them (Ipsos MORI, 2019b, pp. 15-16).

\section{The Liberal Democrats' Sources of Weakness}

In the third place in terms of the number of received votes (but fourth because of the number of parliamentary seats) were the Liberal Democrats. In the election manifesto "Stop Brexit. Build a Brighter Future" they proposed to "tackle climate change by reaching $80 \%$ renewable energy by 2030 and improving the energy efficiency of homes; bring in a $1 p$ rise in income tax to spend on health and social care; spend $£ 10,6$ bln more a year on schools and hire 20.000 more teachers; introduce a legal, regulated market for cannabis" (BBC

of Parliament for Chingford (1992-1997). After the constituency's abolition he has represented Chingford and Woodford Green since 1997. In the Shadow Cabinet he was the Secretary of State for Work for Social Security (1997-1999) and Defence (1999-2001) until he became the Leader of the Conservative Party (and the opposition) (2001-2003). In David Cameron's Cabinet he was the Secretary of State for Work and Pensions (2010-2016). He was the chairman of B. Johnson campaign during the 2019 UK general election. 
News, 2019b). Moreover, the Liberal Democrats offered 30 hours a week of free childcare for all families with both parents working (unless either parent earns more than $£ 100.000$ a year); $20 \%$ rise in minimum wages for people working on zero-hours contracts; building 300.000 new homes a year; freeze train fares (with simultaneous spending $£ 3$ billion a year on enhancements to the existing rail infrastructure); reducing of air passengers duties for people who take no more than two international return flights a year; double the number of refugees taken in by the UK and resettle them under the Vulnerable Person Resettlement Scheme. The simple assumption that new or higher expenditures were to be covered by new or higher taxes was questioned by some economic analysts, who indicated that "this is very much out of fashion style at the Treasury which prefers everything to go into a central pot. The manifesto says the (frequent) air passengers' duty rise will go to the fight against climate change, business taxes will pay for an increase in free childcare and an extension of free school meals. The problem is that if any of these sources of funding falls short individually, will they really defund the spending promises associated with it?" (BBC News, 2019c). The Liberal Democrats had the clear-cut (although radical) opinion about Brexit promising "to stop this mess, revoke Article 50 (of the Treaty on European Union) and stay in the EU. In other circumstances, we will continue to fight for a people's vote with the option to stay in the EU, and in that vote we would passionately campaign to keep the UK in the EU" (Liberal Democrats, 2019, p. 11). Another way to emphasize they recognized Brexit as the most important issue was to place it at the beginning of the manifesto (as the first topic after the introduction). Regardless of whether their proposals might seem interesting to the pro-European voters or not, the Liberal Democrats were just a party of tactical choice. "The Liberals have never looked like winning an election since Lloyd George's day. They have offered an electoral dustbin between political polarities, a media-cosseted Westminster club with peerage auction for richer donors on the side. Liberals failed to capitalize on regionalism or nationalism. They were never truly radical, and in coalition were a broken reed. For the past year, the party has been a convalescent home for wounded warriors from the major parties, a gesture voters have treated with derision" (Jenkins, 2019, p. 4). A political weakness in comparison with the Conservative Party and the Labor Party closely correlated to the Liberal Democrats leader Jo Swinson's lack of visibility contrasting with a distinctive (positive or negative) image of B. Johnson and J. Corbyn. Undoubtedly, she was not a charismatic politician and even in her constituency, she had not strong and steady support as proved by the loss of the seat in the 2015 general election. Moreover, she was criticized by the left-wing Liberal Democrats for not continuing (former leader) Tim Farron's attempts to transform the party's ideological profile into a more social-democratic. But the main problem was that J. Swinson served as a Parliamentary Private Secretary to Deputy Prime Minister (Nick Clegg) and Parliamentary Under-Secretary of State for Employment Relations and Postal Affairs in a coalition government with the Conservative Party which made her unreliable as a strong advocate of immediate stopping of Brexit during the 2019 general election. 


\section{The SNP Enhanced Position in Scotland}

Although nominated its candidates only in Scottish constituencies, the SNP obtained quite good electoral result at the national level by the number of both received votes (1.242.380, i.e. $3,9 \%)$ and gained seats $(81,4 \%$, i.e. 48 out of 59$)$. But the real scale of its success was only visible on the regional (i.e. Scottish) level on which for the Party voted $45 \%$ of the electorate (compared to the Conservatives, Labor and Liberal Democrats with respectively 25,1\%, $18.6 \%$ and $9,50 \%$ of voters support). The spectacular victory of the 2015 general election (i.e. 50 seats gaining) was almost repeated because the SNP gained 13 seats over those won in 2017. The Scottish Nationalists defeated even Liberal Democrats' leader Jo Swinson in East Dunbartonshire. After the election's provisional results were announced, the SNP leader Nicola Sturgeon stated that the scale of victory far exceeded her expectations.

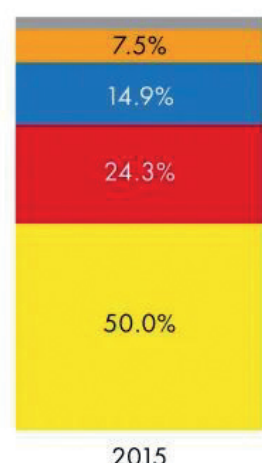

2015

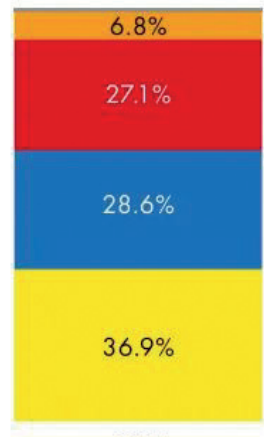

2017

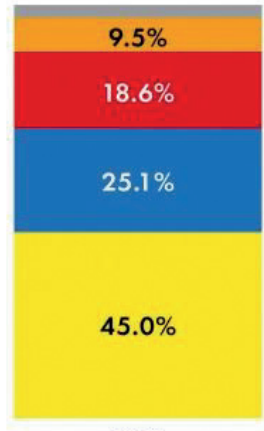

2019

Figure 3. Share of the vote won by each party in Scotland Source: The Scottish Parliament, 2019.

What convinced most of Scots to vote for the SNP were especially announcements of calling the next UK Government "to match Scottish per capita NHS spending, which will deliver increased funding for Scotland; (...) guarantee that trade deals will not undermine the founding principles of the NHS nor open it to profit driven exploitation; (...) invest in public services and the economy, starting with a reversal of the cut Scotland has seen to its real-terms budget; (...) end to policies which are pushing people into poverty, debt and desperation including ending the two child cap on tax credits and associated rape clause, an end to the punitive benefit sanctions regime, and to halt the Universal Credit (...); income replacement benefits of at least inflation; (...) for the devolution (i.e. transferring to the Scottish Parliament competences) of drug policy (...); to ensure that pensions continue to rise by inflation, earnings or 2,5\% - whatever is highest. (The SNP) will seek the devolution of immigration powers so Scotland can have a migration system that works for our economy and society; (...) devolution of employment law so that the Scottish Parliament can protect 
workers' rights, increasing the living wage and end the age discrimination of the statutory living wage" (The Scottish National Party, 2019, pp. 4-5). On the climate change, the SNP declared to push the next UK Government to enhance competencies of a regional authorities and to "propose a 'green energy deal' to ensure eco-friendly initiatives have long-term security" (The Telegraph, 2019). But two main issues of the Party's manifesto were Brexit and the second Scottish independence referendum. Reminding that the Scots overwhelmingly voted for remaining the UK in the EU (in 2016 referendum) and calling into question the possibility of reaching mutually satisfactory solutions in the UK (including Scotland) and the EU relations in case of Brexit (in short-term perspective), the SNP postulated the second referendum on the UK withdrawal from the EU or (even) to revoke of Article 50 of the TUE if necessary to avoid a "no-deal" Brexit. And because the Scottish Nationalists simultaneously pointed that "Scotland should be an independent country in a new partnership of equals with the rest of the UK and our European neighbors" (The Scottish National Party, 2019, p. 8), no one could be surprised to see in their manifesto a request to hold a second Scottish independence referendum. It was even more justified in the context of a very possible Brexit perspective that could not be considered by the people who voted in the 2014 Scottish independence referendum. There were no doubts that "Nicola Sturgeon wants an agreement with the UK government before holding a vote, but has seen the Conservatives rule this out completely and Labor say it wouldn't be on the table in the 'early years' of a new government. If Ms. Sturgeon is to get a referendum on her 2020 timetable, something needs to give - and she wants the result of this election to send a big message to both potential prime ministers about 'Scotland's future being in Scotland's hands'” (BBC News, 2019d). As seemed the least important rationale of the Scots' support for this action plan was the SNP leader personality, although N. Sturgeon was widely acclaimed for both her loyalty (to Scotland, the SNP and its former leader Alex Salmond) and effectiveness (in her political career and the successful leadership).

\section{Conclusions}

Analysis of the 2019 general election results leads to the conclusion of a causal relationship between the number of votes obtained by each of the presented parties and their proposals on Brexit. In this crucial (as indicated above) issue, voters preferences were determined by a combination of various factors among which the most important were: the sense of being bound by a decision taken in the 2016 referendum (which automatically reduced the level of support of parties demanding a repeat voting on that matter or an immediate halt to the UK withdrawal from the EU process), tiredness of extending (for almost the last three years) negotiations on Brexit conditions (which resulted in the widespread feeling that any decision was better than no decision), and an expectation of concrete (i.e. understandable) solution being the continuity of ongoing actions or at least not impressing that the British made a colossal mistake during the 2016 referendum. Among main parties functioning on the 
national level only the Conservatives met all those requirements while the Labor hesitated between the "soft Brexit" formula and the second referendum on the UK withdrawal from the EU (which could result even in "no Brexit" option) and the Liberal Democrats called for "stopping this mess" through a total reversal of the policy over the former three years. The simple Conservative slogan "get Brexit done" was far more convincing than the Labor's intricate considerations or intrusive pro-European radicalism of the Liberal Democrats. The Scottish National Party, however, was in a different situation (because in the 2016 referendum $62 \%$ of the Scots were in favor of the UK remaining the EU membership) and its electoral slogan "stop Brexit" (in connection with demand for second Scotland's independence referendum in case of the UK withdrawal from the EU) were perceived by the regional community as acting in the interest of Scotland. In Scotland's case (as in no other country of the UK), Brexit was only the second importance issue however closely connected with the first one, i.e. the Scottish future as the part of the UK or as an independent country. The overall conclusion is that simple (in content and form) messages, clear (or even populistic) promises (especially in issues of the highest public interest) and uncompromising attitude of leaders were the main reasons of the Conservatives (in the whole UK) and Scottish Nationalists (in Scotland) victories in the 2019 general election. The lack of any of those factors (unclear proposals of the Labor and controversial figure of their leader as well as incorrect identification of the electorate expectations by the Liberal Democrats) caused a loss in the election, which meant the defeat of the battle of Brexit.

To not disappoint their supporters (and the rest of voters as well), the Conservatives have to take actions promised in the election manifesto "Get Brexit Done: Unleash Britain's Potential". Therefore, it can be assumed that soft or hard (i.e. based on a trade agreement with the EU or not) Brexit will become a fact in the near or distant future. However, it is still impossible to determine its long-term effects in both the economic and political spheres. One of the worst (although not excluded) scenarios is the one in which the withdrawal from the EU will cause the UK "dismantling” by gradually increasing centrifugal trends in Scotland (which perhaps would prefer to be a member of the EU even at the sacrifice of its union with England) and Northern Ireland (which will probably develop its close cooperation with the Republic of Ireland in the frames of the EU's customs union and the Common Market while the rest of the UK will exist beyond these structures). In such a case the battle of Brexit will prove to be not won but lost not only by the Conservatives but by the whole UK.

\section{References:}

BBC News. (2019a). Election 2019: How significant is immigration to the UK? Retrieved from: https:// www.bbc.com/news/election-2019-50658968.

BBC News. (2019b). General election 2019: A simple guide to the Liberal Democrats. Retrieved from: https://www.bbc.com/news/election-2019-50343417. 
BBC News. (2019c).Liberal Democrat manifesto 2019: 12 key policies explained. Retrieved from: https:// www.bbc.com/news/election-2019-50459123.

BBC News. (2019d). SNP manifesto 2019: key policies explained. Retrieved from: https://www.bbc.com/ news/election-2019-50561073.

Becker, S.O., Fetzer, T., Novy, D. (2017). "Who voted for Brexit? A comprehensive district-level analysis". Economic Policy, 32, 601-650. DOI: https://doi.org/10.1093/epolic/eix012.

Channel4. (2012). Boris Johnson: classic Tory or political maverick?. Retrieved from: https://www. channel4.com/news/borish-johnson-classic-tory-or-political-maverick.

Edwards, G., Isaby, J. (2008). Boris v. Ken: How Boris Johnson Won London. London: Politico's Publishing. Ipsos MORI. (2019a). Jeremy Corbyn has lowest leadership satisfaction rating for any opposition leader since 1977. Retrieved from: https://www.ipsos.com/ipsos-mori/en-uk/jeremy-corbyn-has-lowestleadership-satisfaction-rating-any-opposition-leader-1977.

Ipsos MORI. (2019b). Political Monitor. September 2019. Retrieved from: https://www.ipsos.com/sites/ default/files/ct/news/documents/2019-09/september-2019-pm-charts.pdf.

Jenkins, S. (2019, December 16). “The Lib Dems helped the Tories to victory again. Now they should disband". The Guardian.

Liberal Democrats. (2019). Stop Brexit. Build a Brighter Future. Liberal Democrats Manifesto 2019, Basildon: Liberal Democrats.

Mason, R. (2019, December 13). "Five reasons the Tories won the election". The Guardian.

Proctor, K. (2019, December 13). "Five reasons why Labor lost the election”. The Guardian.

The Conservative and Unionist Party. (2019). Get Brexit Done: Unleash Britain's Potential. The Conservative and Unionist Party Manifesto 2019. London: the Conservative and Unionist Party.

The Labor Party. (2019). It's Time for Real Change. The Labor Party Manifesto 2019. London: the Labor Party.

The New York Times. (2016). Luck Runs Out for a Leader of 'Brexit' Campaign. Retrieved from: https:// www.nytimes.com/2016/07/01/world/europe/boris-johnson-brexit-conservatives.html.

The Scottish National Party. (2019). Stronger for Scotland. Manifesto 2019. Glasgow: the Scottish National Party.

The Scottish Parliament. (2019). How Scotland voted: UK General Election 2019. Retrieved from: https:// spice-spotlight.scot/2019/12/13/how-scotland-voted-uk-general-election-2019.

The Telegraph. (2019). SNP manifesto 2019: key policies, at a glance. Retrieved from: https://www. telegraph.co.uk/politics/0/manifesto-scottish-national-party-snp-2019-election

The Times. (2017). Abbot declared support for British defeat in Northern Ireland. Retrieved from: https://www.thetimes.co.uk/edition/election-2017/abbott-declared-support-for-ira-defeat-of-britainrp79dvvmk.

Uberoi, E. (2016). European Union Referendum 2016. London: House of Commons Library.

Uberoi, E., et al. (2020). General Election 2019: results and analysis. London: House of Commons Library.

YouGov. (2019a). How Britain voted in the 2019 general election. Retrieved from: https://yougov.co.uk/ topics/politics/articles-reports/2019/12/17/how-britain-voted-2019-general-election.

YouGov. (2019b). Which issues will decide the general election. Retrieved from: https://yougov.co.uk/ topics/politics/articles-reports/2019/11/07/which-issues-will-decide-general-election. 